\title{
Customers' Perception towards Service Quality Dimensions of the Public and Private Sector Banks - An Empirical Study in Erode District of Tamil Nadu
}

\author{
S. Anbarasu ${ }^{1}$ and D. Muthamizh Vendan Murugavel ${ }^{2 *}$ \\ ${ }^{1}$ Associate Professor, Department of Accounting and Finance, College of Business and Economics, Wolkite \\ University, Wolkite (Guraghe Zone), Ethiopia; anbugac@gmail.com \\ ${ }^{2}$ Associate Professor, School of Commerce and International Business, Dr GRD College of Science, \\ Coimbatore, India; mvmgrd@gmail.com
}

\begin{abstract}
Retail banking in India is currently experiencing a fierce competition as public sector banks, private sector banks and foreign banks are trying to perform their best to expand their respective retail market share. If a bank is incapable of satisfying customers' expectations, it will lose customer-base which, in turn, will result in contraction of market share and adverse impact on profitability. Customer expectations and the need for quality services have substantially increased. As customers become better educated, they demand new products, better and more reliable delivery, as well as more responsive services. As a consequence, to improve competitiveness, banks have to understand customer needs and expectations and satisfy their customers by providing better products and services. Against this backdrop, the present study has been undertaken to analyse the service quality dimensions of the public sector and private sector banks in Erode District of Tamil Nadu.
\end{abstract}

Keywords: Perceived Service Quality, Public and Private Sector Banks, Retail Banking

\section{Introduction}

The service sector of the economy is going through a period of almost revolutionary changes in which the established way of doing business continue to be shunted aside. It has emerged as the fastest expanding sector with implications for other sectors especially manufacturing, employment and trade. Sectors like banking, insurance, real estate, business and trade, hotels, restaurants, transport, storage and communication are the major contributions to the growth. The financial services sector has experienced a sweeping change leading to stiff competition and larger deregulation. The ultimate scenario is that, now there are too many private and foreign banks constituting the Indian banking industry. However, the banking services are leading the economy to the higher reaches of the growth potential and enhancing the service quality in the banking industry has emerged vital. Without good quality of services, banks will not be able to perform their work effectively. Hence, the present study has been undertaken to examine the perception of the customers towards various service quality dimensions.

* Author for correspondence 


\section{Review of Literature}

Spathis, Petridou and Glaveli [1] empirically asserted that in Greece, the service quality of private sector banks was superior than public sector banks on all dimensions. Suresh Chander, Chandrasekharan Rajendran and Anantharaman [2] explored the level of service quality of three groups of banks in India based on the customers' perception. Mengi and Pooja [3] concluded that customers of public sector banks were more satisfied with the service quality than those of private sector banks. Mohammed Hossain and Shirley Leo [4] exposed that the customers' perceptions were the highest in respect of infrastructure facilities of the bank. Arun Kumar et al. [5] confirmed that the customers distinguish five dimensions of service quality in the case of private retail banking. The five service quality dimensions were defined specifically and comprehensively by Downwindz in Business [6]. Radium Cheng and Teresa Hsu [7] focused on the relationship between service quality and delivery among public, private and foreign banks in Odisha. Deepanjan Das [8] suggested that in Cachar, public sector banks were superior and leading than that of private banks mainly due to trust and reliability, and location factors. Sanjiv Mittal, Rajat Gera and Dharminder Kumar Batra [9] confirmed the pattern of multi-level service quality in retail banking in India, of which the dimension of tangibles as the most influential.

\section{Objective of the Study}

The present study aims to compare the service quality dimensions of the retail banking of public and private sector commercial banks in Erode district.

\section{Methodology}

\subsection{Sampling}

There are 37 commercial banks in operation in Erode District as on March 2014, of which, 21 are public sector banks and 16 are private sector banks. Multi-stage sampling technique has been adopted for the study. In the first stage, 7 commercial banks (4 public sector and 3 private sector) which outnumber in the number of branches were selected out of the 37 commercial banks. In the second stage, 10 per cent of the branches i.e., 16 branches were selected out of the 7 select commercial banks. In the final stage, from each of the branches, 30 customers of savings bank account and 10 customers of current account were chosen purposively to constitute a total sample size of 640 customers.

\subsection{Data Source}

To collect the primary data from 640 sample customers, the questionnaire was constructed based on Likert's scaling technique.

\subsection{Statistical Tools Used}

In order to study the perception of the customers towards service quality, student $t$ test, coefficient of variation, multiple regression analysis, discriminant function analysis and percentage analysis have been employed

\subsection{Hypotheses}

$\mathbf{H}_{0}$ : There is no significant difference between the service quality dimensions of the retail banking of public and private sector commercial banks.

\section{Customers' Perception towards Service Quality Dimensions of the Retail Banking}

To meet the demands of today's banking environment, banks adopt service initiatives as a means to sustain competitive advantage. In this context, the concept of 'Perceived Service Quality' has gained significance and it is the consequence of what consumers expect and what consumers perceive of the service actually delivered by the providers. Therefore, an attempt has been made to find out the perception of the customers towards various service quality dimensions of the select commercial banks such as, assurance of service, empathy, reliability of service, responsiveness, tangibility, competence of employees, communication, understanding the customers, access to service, security and complaint handling system.

\subsection{Level of Acceptance towards Service Quality Dimensions}

The respondents' level of acceptance towards the various service quality dimensions is depicted in Table 1.

Table 1 reveals that, on the whole, the level of acceptance of the customers of the select private and public sector banks relating to the various service quality dimensions considered for the study is good. The mean score of their acceptance level is more in case of Tangibility, 
Table 1. Respondents' level of acceptance towards service quality dimensions

\begin{tabular}{|c|c|c|c|c|c|c|c|}
\hline \multirow{2}{*}{ Service Quality Dimensions } & \multicolumn{5}{|c|}{ Level of Acceptance } & \multirow{2}{*}{ Total } & \multirow{2}{*}{ Mean Score } \\
\hline & $\begin{array}{l}\text { Strongly } \\
\text { Agree }\end{array}$ & Agree & $\begin{array}{c}\text { Neither Agree nor } \\
\text { Disagree }\end{array}$ & Disagree & $\begin{array}{l}\text { Strongly } \\
\text { Disagree }\end{array}$ & & \\
\hline Assurance of Service & $77(12.03)$ & $\begin{array}{c}159 \\
(24.84)\end{array}$ & $143(22.35)$ & $\begin{array}{c}107 \\
(16.72)\end{array}$ & $\begin{array}{c}154 \\
(24.06)\end{array}$ & $\begin{array}{c}640 \\
(100.00)\end{array}$ & 2.84 \\
\hline Empathy & $101(15.78)$ & $\begin{array}{c}134 \\
(20.94)\end{array}$ & $135(21.09)$ & $\begin{array}{c}151 \\
(23.59)\end{array}$ & $\begin{array}{c}119 \\
(18.60)\end{array}$ & $\begin{array}{c}640 \\
(100.00)\end{array}$ & 2.91 \\
\hline Reliability of Service & $\begin{array}{c}94 \\
(14.69) \\
\end{array}$ & $\begin{array}{c}156 \\
(24.38) \\
\end{array}$ & $\begin{array}{c}142 \\
(22.19) \\
\end{array}$ & $\begin{array}{c}161 \\
(25.16) \\
\end{array}$ & $\begin{array}{c}87 \\
(13.58) \\
\end{array}$ & $\begin{array}{c}640 \\
(100.00) \\
\end{array}$ & 3.01 \\
\hline Responsiveness & $89(13.91)$ & $\begin{array}{c}156 \\
(24.38) \\
\end{array}$ & $135(21.09)$ & $\begin{array}{c}156 \\
(24.37) \\
\end{array}$ & $\begin{array}{c}104 \\
(16.25) \\
\end{array}$ & $\begin{array}{c}640 \\
(100.00) \\
\end{array}$ & 2.95 \\
\hline Tangibility & $118(18.44)$ & $\begin{array}{c}197 \\
(30.78)\end{array}$ & $139(21.72)$ & $\begin{array}{c}130 \\
(20.31)\end{array}$ & $56(8.75)$ & $\begin{array}{c}640 \\
(100.00)\end{array}$ & 3.30 \\
\hline Competence of Employees & $90(14.06)$ & $\begin{array}{c}133 \\
(20.78) \\
\end{array}$ & $134(20.94)$ & $\begin{array}{c}152 \\
(23.75) \\
\end{array}$ & $\begin{array}{c}131 \\
(20.47) \\
\end{array}$ & $\begin{array}{c}640 \\
(100.00) \\
\end{array}$ & 2.84 \\
\hline Communication by Employees & $94(14.69)$ & $\begin{array}{c}153 \\
(23.91) \\
\end{array}$ & $141(22.03)$ & $\begin{array}{c}152 \\
(23.75) \\
\end{array}$ & $\begin{array}{c}100 \\
(15.62) \\
\end{array}$ & $\begin{array}{c}640 \\
(100.00) \\
\end{array}$ & 2.98 \\
\hline Understanding the Customers & $105(16.41)$ & $\begin{array}{c}163 \\
(25.47)\end{array}$ & $146(22.81)$ & $\begin{array}{c}140 \\
(21.88)\end{array}$ & $\begin{array}{c}86 \\
(13.43)\end{array}$ & $\begin{array}{c}640 \\
(100.00)\end{array}$ & 3.09 \\
\hline Access to Service & $111(17.34)$ & $\begin{array}{c}162 \\
(25.31) \\
\end{array}$ & $138(21.56)$ & $\begin{array}{c}145 \\
(22.66) \\
\end{array}$ & $\begin{array}{c}84 \\
(13.13) \\
\end{array}$ & $\begin{array}{c}640 \\
(100.00) \\
\end{array}$ & 3.11 \\
\hline Security & $130(20.31)$ & $\begin{array}{c}160 \\
(25.00) \\
\end{array}$ & $137(21.41)$ & $\begin{array}{c}128 \\
(20.00) \\
\end{array}$ & $\begin{array}{c}85 \\
(13.28) \\
\end{array}$ & $\begin{array}{c}640 \\
(100.00) \\
\end{array}$ & 3.18 \\
\hline Complaint Handling System & $65(10.16)$ & $\begin{array}{c}119 \\
(18.59)\end{array}$ & $146(22.81)$ & $\begin{array}{c}171 \\
(26.72)\end{array}$ & $\begin{array}{c}139 \\
(21.72) \\
\end{array}$ & $\begin{array}{c}640 \\
(100.00) \\
\end{array}$ & 2.68 \\
\hline
\end{tabular}

Source: Primary Data. (Figures in parentheses are percentage)

Security, Access to Service, Understanding the Customers and Reliability of Service. Moreover, the least mean score of their level of acceptance is found towards Complaint Handling System as majority of the customers are not satisfied with this service.

\subsection{Variation in the Respondents' Level of \\ Acceptance towards Assurance of Service}

Table 2 shows the variation in the respondents' level of acceptance towards assurance of service analysed by the coefficient of variation.
Table 2. Variation in respondents' level of acceptance towards assurance of service

\begin{tabular}{|c|c|c|c|c|}
\hline Type of Bank & $\begin{array}{c}\text { No. of } \\
\text { Respon } \\
\text { dents }\end{array}$ & $\begin{array}{c}\text { Mean } \\
\text { Score }\end{array}$ & $\begin{array}{c}\text { Standard } \\
\text { Deviation }\end{array}$ & $\begin{array}{c}\text { Coefficient } \\
\text { of Variation }\end{array}$ \\
\hline $\begin{array}{c}\text { Public sector } \\
\text { bank }\end{array}$ & 520 & 10.66 & 1.91 & 17.92 \\
\hline $\begin{array}{c}\text { Private sector } \\
\text { bank }\end{array}$ & 120 & 14.51 & 2.24 & 15.44 \\
\hline Overall & 640 & 11.38 & 2.48 & 21.79 \\
\hline
\end{tabular}

Source: Primary Data; Calculated t value is 19.235 ; Table value at $1 \%$ significance level is 2.584 
Table 2 shows that the variation in the level of acceptance is high among the customers of the public sector banks (17.92\%). The calculated t value is (19.235) greater than the table value (2.584) at 1 per cent level of significance. That is, the null hypothesis is rejected. It means that a significant difference is found between the level of acceptance of the respondents of public and private sector banks towards assurance of service.

\subsection{Variation in the Respondents' Level of Acceptance towards Empathy}

Table 3 shows the variation in respondents' level of acceptance towards empathy analysed with the coefficient of variation.

Table 3. Variation in respondents' level of acceptance towards empathy

\begin{tabular}{|c|c|c|c|c|}
\hline $\begin{array}{c}\text { Type of } \\
\text { Bank }\end{array}$ & $\begin{array}{c}\text { No. of } \\
\text { Respon } \\
\text { dents }\end{array}$ & $\begin{array}{c}\text { Mean } \\
\text { Score }\end{array}$ & $\begin{array}{c}\text { Standard } \\
\text { Deviation }\end{array}$ & $\begin{array}{c}\text { Coefficient } \\
\text { of Variation }\end{array}$ \\
\hline $\begin{array}{c}\text { Public sector } \\
\text { bank }\end{array}$ & 520 & 17.12 & 3.20 & 18.69 \\
\hline $\begin{array}{c}\text { Private sec- } \\
\text { tor bank }\end{array}$ & 120 & 19.26 & 2.97 & 15.42 \\
\hline Overall & 640 & 17.52 & 3.27 & 18.66 \\
\hline
\end{tabular}

Source: Primary Data; Calculated t value is 6.689 ; Table value at $1 \%$ Significance level is 2.584

Table 3 shows that the variation in the acceptance is high among the customers of the public sector banks (18.69\%), followed by the customers of the private sector banks (15.42\%) towards empathy. The mean acceptance score shows that the customers of the private sector banks have high level of acceptance (19.26), followed by the customers of the public sector banks (17.12) towards empathy. The calculated t value is (6.689) greater than the table value (2.584) at 1 per cent level of significance. Thus, the null hypothesis is rejected. Hence, there is a significant difference between the level of acceptance of the respondents of public and private sector banks towards empathy.

\subsection{Variation in the Respondents' Level of Acceptance towards Reliability of Service} Table 4 depicts the variation in respondents' level of acceptance towards reliability of service analysed with the coefficient of variation.

Table 4. Variation in respondents' level of acceptance towards reliability of service

\begin{tabular}{|c|c|c|c|c|}
\hline $\begin{array}{c}\text { Type of } \\
\text { Bank }\end{array}$ & $\begin{array}{c}\text { No. of } \\
\text { Respo } \\
\text { ndents }\end{array}$ & $\begin{array}{c}\text { Mean } \\
\text { Score }\end{array}$ & $\begin{array}{c}\text { Standard } \\
\text { Deviation }\end{array}$ & $\begin{array}{c}\text { Coefficient } \\
\text { of Variation }\end{array}$ \\
\hline $\begin{array}{c}\text { Public sector } \\
\text { bank }\end{array}$ & 520 & 14.98 & 2.95 & 19.69 \\
\hline $\begin{array}{c}\text { Private sec- } \\
\text { tor bank }\end{array}$ & 120 & 15.50 & 2.40 & 15.48 \\
\hline Overall & 640 & 15.08 & 2.86 & 18.97 \\
\hline
\end{tabular}

Source: Primary Data. Calculated t value is 1.802 ; Table value at $5 \%$ significance level is 1.964 .

Table 4 shows that the variation in the acceptance is high among the customers of the public sector banks (19.69\%), followed by the customers of the private sector banks (15.48\%) towards reliability of service. The customers of the private sector banks have high level of acceptance towards reliability of service (15.50), followed by the customers of the public sector banks (14.98). The calculated $t$ value is (1.802) less than the table value (1.964) at 5 per cent level of significance. Hence the null hypothesis is accepted. Therefore, there is no significant difference between the acceptance level of the respondents of public and private sector banks towards reliability of service.

\subsection{Variation in the Respondents' Level of \\ Acceptance towards Responsiveness}

Table 5 explains the variation in the respondents' level of acceptance towards responsiveness analysed with the coefficient of variation.

Table 5. Variation in respondents' level of acceptance towards responsiveness

\begin{tabular}{|c|c|c|c|c|}
\hline $\begin{array}{c}\text { Type of } \\
\text { Bank }\end{array}$ & $\begin{array}{c}\text { No. of } \\
\text { Respon } \\
\text { dents }\end{array}$ & $\begin{array}{l}\text { Mean } \\
\text { Score }\end{array}$ & $\begin{array}{l}\text { Standard } \\
\text { Deviation }\end{array}$ & $\begin{array}{l}\text { Coefficient } \\
\text { of Variation }\end{array}$ \\
\hline $\begin{array}{c}\text { Public sec- } \\
\text { tor bank }\end{array}$ & 520 & 11.60 & 2.54 & 21.90 \\
\hline $\begin{array}{l}\text { Private sec- } \\
\text { tor bank }\end{array}$ & 120 & 12.70 & 2.31 & 18.19 \\
\hline Overall & 640 & 11.80 & 2.53 & 21.44 \\
\hline
\end{tabular}

Source: Primary Data; Calculated t value is 4.357; Table value at $1 \%$ significance level is 2.584 
Table 5 shows that the variation in the level of acceptance is high among the customers of the public sector banks (21.90\%), followed by the customers of the private sector banks (18.19\%) towards responsiveness. The customers of the private sector banks have higher level of acceptance (12.70), followed by the customers of the public sector banks (11.60) towards the responsiveness. The calculated t value is (4.357) less than the table value (2.584) at 1 per cent level of significance. Therefore, the null hypothesis is accepted. That is, there is no significant difference between the acceptance level of the respondents of public and private sector banks towards responsiveness.

\subsection{Variation in the Respondents' Level of Acceptance towards Tangibility}

Table 6 shows the variation in respondents' level of acceptance towards tangibility which has been analysed by applying coefficient of variation.

Table 6. Variation in respondents' level of acceptance towards tangibility

\begin{tabular}{|c|c|c|c|c|}
\hline $\begin{array}{c}\text { Type of } \\
\text { Bank }\end{array}$ & $\begin{array}{c}\text { No. of } \\
\text { Respon } \\
\text { dents }\end{array}$ & $\begin{array}{c}\text { Mean } \\
\text { Score }\end{array}$ & $\begin{array}{c}\text { Standard } \\
\text { Deviation }\end{array}$ & $\begin{array}{c}\text { Coefficient of } \\
\text { Variation }\end{array}$ \\
\hline $\begin{array}{c}\text { Public sector } \\
\text { bank }\end{array}$ & 520 & 13.34 & 2.47 & 18.52 \\
\hline $\begin{array}{c}\text { Private sec- } \\
\text { tor bank }\end{array}$ & 120 & 12.53 & 2.00 & 15.96 \\
\hline Overall & 640 & 13.19 & 2.41 & 18.27 \\
\hline
\end{tabular}

Source: Primary Data; Calculated t value is 3.352 ; Table value at $1 \%$ significance level is 2.584

Table 6 shows that the variation in the acceptance is high among the customers of the public sector banks (18.52\%), followed by the customers of the private sector banks (15.96\%) towards tangibility. The customers of the public sector banks have high level of acceptance with the tangibility dimension of service quality (13.34), followed by the customers of the private sector banks (12.53). The calculated $t$ value is (3.352) greater than the table value (2.584) at 1 per cent level of significance. Hence, the null hypothesis is rejected. Thus, there is a significant difference between the acceptance level of the respondents of public and private sector banks towards tangibility dimension of service quality.

\subsection{Variation in the Respondents' Level of Acceptance towards Competence of Employees}

Table 7 depicts the variation in the respondents' level of acceptance towards competence of employees analysed by the coefficient of variations.

Table 7. Variation in respondents' level of acceptance towards competence of employees

\begin{tabular}{|c|c|c|c|c|}
\hline $\begin{array}{c}\text { Type of } \\
\text { Bank }\end{array}$ & $\begin{array}{c}\text { No. of } \\
\text { Respon } \\
\text { dents }\end{array}$ & $\begin{array}{c}\text { Mean } \\
\text { Score }\end{array}$ & $\begin{array}{c}\text { Standard } \\
\text { Deviation }\end{array}$ & $\begin{array}{c}\text { Coefficient } \\
\text { of } \\
\text { Variation }\end{array}$ \\
\hline $\begin{array}{c}\text { Public sec- } \\
\text { tor bank }\end{array}$ & 520 & 13.65 & 3.44 & 25.20 \\
\hline $\begin{array}{c}\text { Private sec- } \\
\text { tor bank }\end{array}$ & 120 & 16.63 & 3.10 & 18.64 \\
\hline Overall & 640 & 14.21 & 3.57 & 25.12 \\
\hline
\end{tabular}

Source: Primary Data; Calculated t value is 8.707 ; Table value at $1 \%$ significance level is 2.584 .

Table 7 shows that the variation in the acceptance is high among the customers of the public sector banks (25.20\%), followed by the customers of the private sector banks (18.64\%) towards competence of employees. The customers of the private sector banks have high level of acceptance (16.63), followed by the customers of the public sector banks (13.65) towards the competence of employees. The calculated $t$ value is $(8.707)$ greater than the table value (2.584) at 1 per cent level of significance. Thus, the null hypothesis is rejected. That is, a significant difference is found between the level of acceptance of the respondents of public and private sector banks towards competence of the employees.

\subsection{Variation in the Respondents' Level of Acceptance towards Communication by Employees}

Table 8 explains the variation in the respondents' level 
of acceptance towards communication by employees analysed by the coefficient of variation.

Table 8. Variation in respondents' level of acceptance towards communication

\begin{tabular}{|c|c|c|c|c|}
\hline $\begin{array}{c}\text { Type of } \\
\text { Bank }\end{array}$ & $\begin{array}{c}\text { No. of } \\
\text { Respon } \\
\text { dents }\end{array}$ & $\begin{array}{c}\text { Mean } \\
\text { Score }\end{array}$ & $\begin{array}{c}\text { Standard } \\
\text { Deviation }\end{array}$ & $\begin{array}{c}\text { Coefficient } \\
\text { of Variation }\end{array}$ \\
\hline $\begin{array}{c}\text { Public sec- } \\
\text { tor bank }\end{array}$ & 520 & 11.82 & 2.50 & 21.15 \\
\hline $\begin{array}{c}\text { Private sec- } \\
\text { tor bank }\end{array}$ & 120 & 12.41 & 2.22 & 17.89 \\
\hline Overall & 640 & 11.93 & 2.46 & 20.62 \\
\hline
\end{tabular}

Source: Primary Data; Calculated t value is 2.377; Table value at $5 \%$ significance level is 1.964

Table 8 shows that the variation in the acceptance is high among the customers of the public sector banks $(21.15 \%)$, followed by the customers of the private sector banks $(17.89 \%)$ towards communication. The calculated $\mathrm{t}$ value is (2.377) greater than the table value (1.964) at 5 per cent level of significance. Thus, the null hypothesis is rejected. Therefore, a significant difference is found between the level of acceptance of the respondents of public and private sector banks towards communication.

\subsection{Variation in the Respondents' Level of Acceptance towards the Dimension of Understanding the Customers}

Table 9 shows the variation in the respondents' level of acceptance towards the dimension of understanding the customers analysed by the coefficient of variation.

Table 9. Variation in respondents' level of acceptance towards understanding the customers

\begin{tabular}{|c|c|c|c|c|}
\hline $\begin{array}{c}\text { Type of } \\
\text { Bank }\end{array}$ & $\begin{array}{c}\text { No. of } \\
\text { Respon } \\
\text { dents }\end{array}$ & $\begin{array}{c}\text { Mean } \\
\text { Score }\end{array}$ & $\begin{array}{c}\text { Standard } \\
\text { Deviation }\end{array}$ & $\begin{array}{c}\text { Coefficient } \\
\text { of Variation }\end{array}$ \\
\hline $\begin{array}{c}\text { Public sector } \\
\text { bank }\end{array}$ & 520 & 9.20 & 1.96 & 21.30 \\
\hline $\begin{array}{c}\text { Private sec- } \\
\text { tor bank }\end{array}$ & 120 & 9.62 & 2.35 & 24.43 \\
\hline Overall & 640 & 9.28 & 2.05 & 22.09 \\
\hline
\end{tabular}

Source: Primary Data; Calculated t value is 2.006; Table value at $5 \%$ significance level is 1.964 .

Table 9 shows that the variation in the acceptance is high among the customers of the private sector banks (24.43\%), followed by the customers of the public sector banks $(21.30 \%)$ towards understanding the customers. The calculated $t$ value is (2.006) greater than the table value (1.964) at 5 per cent level of significance. That is, the null hypothesis is rejected. Hence, a significant difference is found between the acceptance level of the respondents of public and private sector banks towards understanding the customers.

\subsection{Variation in the Respondents' Level of Acceptance towards Access to Services}

Table 10 depicts the variation in the respondents' level of acceptance towards access to services analysed with the coefficient of variation.

Table 10. Variation in respondents' level of acceptance towards access to services

\begin{tabular}{|c|c|c|c|c|}
\hline $\begin{array}{c}\text { Type of } \\
\text { Bank }\end{array}$ & $\begin{array}{c}\text { No. of } \\
\text { Respon } \\
\text { dents }\end{array}$ & $\begin{array}{c}\text { Mean } \\
\text { Score }\end{array}$ & $\begin{array}{c}\text { Standard } \\
\text { Deviation }\end{array}$ & $\begin{array}{c}\text { Coefficient } \\
\text { of Variation }\end{array}$ \\
\hline $\begin{array}{c}\text { Public sector } \\
\text { bank }\end{array}$ & 520 & 15.51 & 2.73 & 17.60 \\
\hline $\begin{array}{c}\text { Private sec- } \\
\text { tor bank }\end{array}$ & 120 & 15.73 & 2.52 & 16.02 \\
\hline Overall & 640 & 15.55 & 2.69 & 17.30 \\
\hline
\end{tabular}

Source: Primary Data; Calculated t value is 0.784 ; Table value at $5 \%$ significance level is 1.964 .

Table 10 shows that the variation in the acceptance is high among the customers of the public sector banks $(17.60 \%)$, followed by the customers of the private sector banks (16.02\%) towards access to services. The customers of the private sector banks have higher level of acceptance in terms of mean score (15.73), followed by the customers of the public sector banks (15.51) towards access to services. The calculated t value is (0.784) less than the table value (1.964) at 5 per cent level of significance. Therefore, the null hypothesis is accepted. Hence no significant difference is found between the acceptance level of the respondents of public and private sector banks towards access to services.

\subsection{Variation in the Respondents' Level of Acceptance towards Security}


Table 11 explains the variation in the respondents' level of acceptance towards security analysed by the coefficient of variation.

Table 11. Variation in respondents' level of acceptance towards security

\begin{tabular}{|c|c|c|c|c|}
\hline Type of Bank & $\begin{array}{c}\text { No. of } \\
\text { Respon } \\
\text { dents }\end{array}$ & $\begin{array}{c}\text { Mean } \\
\text { Score }\end{array}$ & $\begin{array}{c}\text { Standard } \\
\text { Deviation }\end{array}$ & $\begin{array}{c}\text { Coefficient } \\
\text { of Variation }\end{array}$ \\
\hline $\begin{array}{c}\text { Public sector } \\
\text { bank }\end{array}$ & 520 & 12.63 & 2.59 & 20.51 \\
\hline $\begin{array}{c}\text { Private sector } \\
\text { bank }\end{array}$ & 120 & 13.33 & 2.33 & 17.48 \\
\hline Overall & 640 & 12.76 & 2.56 & 20.06 \\
\hline
\end{tabular}

Source: Primary Data; Calculated t value is 2.725 ; Table value at $1 \%$ significance level is 2.584 .

Table 11 shows that the variation in the acceptance is high among the customers of the public sector banks (20.51\%), followed by the customers of the private sector banks $(17.48 \%)$ towards security dimension of the service quality. The calculated $t$ value is (2.725) greater than the Table value (2.584) at 1 per cent level of significance. Therefore, the null hypothesis is rejected. Thus, a significant difference is found between the level of acceptance of the respondents of public and private sector banks towards security.

\subsection{Variation in the Respondents' Level of Acceptance towards Complaint Handling System}

Table 12 shows the variation in respondents' level of acceptance towards complaint handling system analysed with the coefficient of variation.

Table 12. Variation in respondents' level of acceptance towards complaint handling system

\begin{tabular}{|c|c|c|c|c|}
\hline $\begin{array}{c}\text { Type of } \\
\text { Bank }\end{array}$ & $\begin{array}{c}\text { No. of } \\
\text { Respon } \\
\text { dents }\end{array}$ & $\begin{array}{c}\text { Mean } \\
\text { Score }\end{array}$ & $\begin{array}{c}\text { Standard } \\
\text { Deviation }\end{array}$ & $\begin{array}{c}\text { Coefficient of } \\
\text { Variation }\end{array}$ \\
\hline $\begin{array}{c}\text { Public sec- } \\
\text { tor bank }\end{array}$ & 520 & 7.68 & 2.29 & 29.82 \\
\hline $\begin{array}{c}\text { Private sec- } \\
\text { tor bank }\end{array}$ & 120 & 9.67 & 2.18 & 22.54 \\
\hline Overall & 640 & 8.06 & 2.40 & 29.78 \\
\hline
\end{tabular}

Source: Primary Data; Calculated t value is 8.609 ; Table value at $1 \%$ significance level is 2.584 .
Table 12 shows that the variation in the acceptance is high among the customers of the public sector banks (29.82\%), followed by the customers of the private sector banks (22.54\%) towards complaint handling system. The calculated $t$ value is (8.609) greater than the Table value (2.584) at 1 per cent level of significance. Hence, the null hypothesis is rejected. Therefore, a significant difference is found between the level of acceptance of the respondents of public and private sector banks towards complaint handling system prevailing in the banks.

\subsection{Variation in the Respondents' Level of Acceptance towards the Overall Service Quality Dimensions}

Table 13 depicts the variation in respondents' level of acceptance towards the overall service quality dimension analysed by the coefficient of variation.

Table 13. Variation in respondents' level of acceptance towards overall service quality

\begin{tabular}{|c|c|c|c|c|}
\hline Type of & $\begin{array}{c}\text { No. of } \\
\text { Respon } \\
\text { Bank }\end{array}$ & Mean & Standard & Coefficient \\
\hline $\begin{array}{c}\text { Public sec- } \\
\text { tor bank }\end{array}$ & 520 & 138.19 & 8.19 & 5.93 \\
\hline $\begin{array}{c}\text { Private sec- } \\
\text { tor bank }\end{array}$ & 120 & 151.88 & 12.05 & 7.93 \\
\hline Overall & 640 & 140.76 & 10.49 & 7.45 \\
\hline
\end{tabular}

Source: Primary Data; Calculated t value is 14.959 ; Table value at $1 \%$ significance level is 2.584 .

Table 13 shows that the variation in the acceptance is high among the customers of the private sector banks (7.93\%), followed by the customers of the public sector banks (5.93\%) towards overall service quality. The calculated $t$ value is (14.959) greater than the table value (2.584) at 1 per cent level of significance. Thus, the null hypothesis is rejected. That is, there is a significant difference between the level of acceptance of the respondents of public and private sector banks towards overall service quality of the select commercial banks.

\subsection{Impact of Socio-Economic Variables on the Service Quality}

An attempt has been made to examine the effect of the personal variables on the service quality of the retail 
banking in the select commercial banks in Erode district by applying multiple regression analysis.

Table 14. Impact of Socio-Economic variables on the service quality (Public Sector)

\begin{tabular}{|c|c|c|c|c|}
\hline $\begin{array}{c}\text { Independent } \\
\text { Variables }\end{array}$ & $\mathbf{B}$ & $\begin{array}{c}\text { Std. } \\
\text { Error }\end{array}$ & $\mathbf{t}$ & Sig. \\
\hline (Constant) & 135.958 & 2.673 & - & - \\
\hline Gender & 1.252 & 1.188 & 1.054 & Ns \\
\hline Age & -0.0844 & 0.476 & -0.177 & Ns \\
\hline Educational status & -0.253 & 0.434 & -0.584 & Ns \\
\hline Monthly income & -0.0449 & 0.446 & -0.101 & Ns \\
\hline Type of account & 1.457 & 0.837 & 1.742 & Ns \\
\hline
\end{tabular}

Source: Primary Data. Ns: Not significant; Calculated R value is 0.096; Calculated $\mathrm{R}$ square value is 0.009 ; Calculated $\mathrm{F}$ value is 0.965 .

Table 14 shows a low correlation (0.096) between the service quality of the retail banking in the public sector commercial banks and the select independent variables. The $\mathrm{R}$ square denotes that together the independent variables have accounted for 0.90 per cent of variation in the service quality of these banks. The F value indicates that the multiple correlation coefficients are not significant. None of the independent variables has any impact on the service quality of the retail banking in the public sector commercial banks in Erode district.

Table 15. Impact of Socio-Economic variables on the service quality (Private Sector)

\begin{tabular}{|c|c|c|c|c|}
\hline $\begin{array}{c}\text { Independent } \\
\text { Variables }\end{array}$ & $\mathbf{B}$ & $\begin{array}{c}\text { Std. } \\
\text { Error }\end{array}$ & $\mathbf{t}$ & Sig. \\
\hline (Constant) & 136.819 & 6.673 & - & - \\
\hline Gender & -0.665 & 3.007 & -0.221 & Ns \\
\hline Age & 1.488 & 1.467 & 1.014 & Ns \\
\hline Educational status & 1.226 & 1.406 & 0.872 & Ns \\
\hline Monthly salary & -0.285 & 1.222 & -0.233 & Ns \\
\hline Type of account & 7.423 & 2.651 & 2.801 & $* *$ \\
\hline
\end{tabular}

Source: Primary Data. Ns: Not significant ${ }^{* *}$ Significant at $1 \%$ level; Calculated $\mathrm{R}$ value is 0.317 ; Calculated $\mathrm{R}$ square value is 0.100 ; Calculated $\mathrm{F}$ value is 2.539 .

Table 15 exposes a low correlation (0.317) between the service quality of the retail banking in the private commercial banks and the selected independent variables. The $\mathrm{R}$ square denotes that together the independent variables have accounted for 10 per cent of variation in the service quality of the private banks. The $\mathrm{F}$ value indicates that the multiple correlation coefficients are significant. However, type of account of the respondents alone has significantly impacted the service quality of the retail banking in the private commercial banks.

Table 16. Impact of Socio-Economic variables on the service quality (Overall)

\begin{tabular}{|c|c|c|c|c|}
\hline $\begin{array}{c}\text { Independent } \\
\text { Variables }\end{array}$ & $\mathbf{B}$ & $\begin{array}{c}\text { Std. } \\
\text { Error }\end{array}$ & $\mathbf{t}$ & Sig. \\
\hline (Constant) & 134.752 & 2.937 & - & - \\
\hline Gender & 2.315 & 1.293 & 1.790 & Ns \\
\hline Age & -0.048 & 0.542 & -0.089 & Ns \\
\hline Educational status & -0.0476 & 0.503 & -0.095 & Ns \\
\hline Monthly salary & 0.0574 & 0.503 & 0.114 & Ns \\
\hline Nature of Account & 2.857 & 0.962 & 2.971 & $\star *$ \\
\hline
\end{tabular}

Source: Primary Data. Ns: Not significant ${ }^{* \star}$ Significant at $1 \%$ level; Calculated $\mathrm{R}$ value is 0.131 ; Calculated $\mathrm{R}$ square value is 0.017 ; Calculated $\mathrm{F}$ value is 2.220 .

Table 16 portrays a low correlation $(0.131)$ between the service quality of the retail banking in the select commercial banks and the select independent variables. The $\mathrm{R}$ square denotes that together the independent variables have contributed for 1.70 per cent of variation in the service quality of the select commercial banks. The F value indicates that the multiple correlation coefficients are significant. Only the type of account of the respondents has significant impact on the service quality of the retail banking in the select commercial banks.

\section{Suggestions and Conclusion}

- The variation in the level of acceptance of customers of private sector banks is more towards the dimension of 'understanding the customers'. So, it is suggested that the private banks should adopt new techniques to understand the customers and their expectations through customer survey campaigns and conferences to analyse their demographic profile, needs, preferences, expectations etc.

- The variation in the level of acceptance of customers of public sector banks is more towards the various service quality dimensions such as assurance of service, empathy, reliability of service, responsiveness, tangibility, competence of employees, communication by employees, access to service, security and complaint handling system. This shows that in all the above said aspects private sector banks are somewhat better than public sector banks. Hence, there is an impera- 
tive need on public sector banks to ensure the quality of the services on all dimensions.

- $\quad$ Overall, the level of acceptance of the customers of the private and public sector banks relating to the various service quality dimensions is good. But the least mean score of customers' level of acceptance is found towards Complaint Handling System, as majority of the customers are not satisfied with this service. Hence, it is suggested that a separate section called "Complaint Handling Cell" has to be established in all the banks to handle the complaints of different types. Customers who approach the cell have to be directed by the group of experts in the cell to get possible solution for their problem within a minimum time.

Retail banking in India is experiencing a fierce competition as public sector banks, private sector banks and foreign banks are trying to perform their best to expand their respective market shares. The significant contribution of the study is the strategy suggested for the leaders in retail banks to enhance the customers' satisfaction and their retention rates. An important element of retail banking is the quality of customer service. The results of the study will certainly induce the authority concerned to take positive measures for improving the effectiveness of retail banking.

\section{References}

1. Spathis Ch., Petridou E., and Glaveli N. An Empirical Study of Service Quality Perspectives in Public and Private Banks. 2002. pp. 3-19. Available: www.link.springer.com

2. Suresh Chandar G.S., Chandrasekharan R., and Anantharaman R.N. "Customer Perceptions of Service Quality in the Banking Sector of a Developing Economy: A Critical Analysis". International Journal of Bank Marketing, Vol. 21(5), pp. 233-242, 2003. Available: www.emeraldinsight.com

3. Mengi P. "Customer Satisfaction with Service Quality: An Empirical Study of Public and Private Sector Banks". IUP Journal of Management Research, September, Vol. 8(9), pp. 7-17, 2009.

4. Mohammed H., and Shirley L. "Customer Perception on Service Quality in Retail B anking in Middle East: The Case of Qatar". International Journal of Islamic and Middle Eastern Finance and Management, Vol. 2(4), pp. 338350, 2009.
5. Arun K.S., Tamilmani B., Mahalingam S., and Vanjikovan M. "Influence of Service Quality on Attitudinal Loyalty in Private Retail Banking: An Empirical Study". The IUP Journal of Management Research, Vol. 9(4), p. 21-38, 2010.

6. Downwindz in Business. "The Five Service Quality Dimensions". 2010 Nov 28. Available: www.bizcovering.com/business/the-five-service-quality-dimensions/

7. Radium C., and Teresa Hsu. "Service Quality: Public, Private, and Foreign Banks". 2013. pp. 1-20. Available: www. slideshare.net

8. Deepanjan D. "A Comparative Study between Private Sector Banks and Public Sector Banks with Respect to Cachar District". [Thesis of Master of Business Administration], NIT, Silchar: Department of Management Studies. 2014 May. pp. 11-66. Available: www.slideshare.net

9. Sanjiv M., Rajat G., Dharminder K.B. "An Evaluation of an Integrated Perspective of Perceived Service Quality for Retail Banking Services in India”. International Journal of Bank Marketing, Vol. 33 (3), p. 330-350, 2015. Available: www. emeraldinsight.com

\section{Other References}

1. Parasuraman A., Zeithml V.A., Berry L.L. "SERVQUAL : A Multiple-item Scale for Measuring Consumer Perceptions of Service Quality". Journal of Retailing, Vol. 64(1), pp. 1240, 1988.

2. Ahmad J., and Kamal N. "Factors Influencing Customer Satisfaction in the Retail Banking Sector in Pakistan". International Journal of Commerce and Management, Vol. 13(2), pp. 29-53, 2003.

3. Archana M. "Customer Services in Public Sector Banks: A Comparative Study of SBBJ and SBI". Indian Journal of Marketing, Vol. 17, pp. 3-10, 1988.

4. Ashok T., and Madan M.T.R. Segmented Service Quality Audit for Banks: An Empirical Analysis, Working Paper No.145, Bangalore: IIM, 1999. pp. 2-9.

5. Brandon R., and Randall C.C. "Being New-Customer Friendly: Determinants of Service Perceptions in Retail Banking". International Journal of Bank Marketing, Vol. 25(1), pp. 56-66, 2006.

6. Charles C.C., Barbara R.L., and Xiaofang D. "Employee and Customer Perceptions of Service Quality: Match or Mismatch? A Study of Chinese Retail Banking". Journal of Asia Pacific Marketing, Vol. 3(1), pp. 24-42, 2004.

7. Dutta K., and Dutta A. "Customer Expectations and Perceptions across the Indian Banking Industry and the Resultant Financial Implications". Journal of Services Research, Vol. 9(1), pp. 31-49, 2009.

8. Eapan V.M. and Ganesh C. "Customer Service in Banks: An Empirical Study”. Vinimaya, Vol. 24(2), pp. 14-26, 2003. 